\title{
SECOND WINTER RECORD OF BLACK GUILLEMOT AT CHURCHILL, MANITOBA
}

ROBERT W. NERO, Wildlife Branch, Box 14, 1495 St. James Street, Winnipeg, Manitoba. R3H OW9

Black Guillemots have previously been reported at Churchill, all but one being summer and fall records. The exception was an adult bird found alive about $6 \mathrm{~km}$ south of town, 8 March $1974 .^{1,2}$ A bird found alive in Churchill on 4 January 1991 is apparently the second winter record. According to natural resources officer Gary Friesen, Dave Lundie saw the bird slip from the grasp of a low-flying Common Raven in town. This happened at midday. The bird was rescued and, because it seemed to be able to fly, Lundie took it to Friesen, who arranged to have it turned over to the Manitoba Wildlife Rehabilitation Organization (MWRO) in Winnipeg, a volunteer organization that treats injured and orphaned wildlife. The bird - still not correctly identified - was transported via Canadian Air in the custody of Joyce Friesen. Garth Ball, of the Manitoba Wildlife Branch, met the plane and brought the bird to me.

in its winter plumage the bird is mostly white, a striking change from the black summer plumage. It was the first live Black Guillemot I had ever seen, but it nearly matched the sketch of one drawn by R. W. Sutton for an article in a 1968 issue of the Blue Jay. ${ }^{2}$
I passed the bird on to MWRO volunteer rehabilitator Janice McCarthy, who cared for it over the weekend and then took it to the Assiniboine Park Zoo hospital where she works. Together with Dr. Gordon Glover, they gave the bird a thorough examination. They found no broken bones or obvious injuries, but the bird was noticeably thin. Despite its spirited appearance and ready consumption of food, it died that evening. An autopsy carried out by Dr. James Neufeld, MWRO president, revealed a large amount of scar tissue resulting from a ruptured liver, but the cause of death was believed to be a strep bacterial infection. Portions of the specimen, a juvenile bird of unknown sex, were turned over to Dr. Spencer G. Sealy, University of Manitoba, Zoology Department.

The occurrence of the Black Guillemot at inland sites in winter in this region, as pointed out both by Best and Sirois, is probably related to the large numbers that overwinter on leads (open water) in the pack-ice of Hudson Bay. ${ }^{1,3}$ This could be the origin of a bird photographed near Yellowknife on 26 November 1988 (first Northwest Territories record), another recorded on 21 November 1988 near Fairview, Alberta, (first Alberta record), one at Regina on 26 November 1988 (first Saskatchewan 


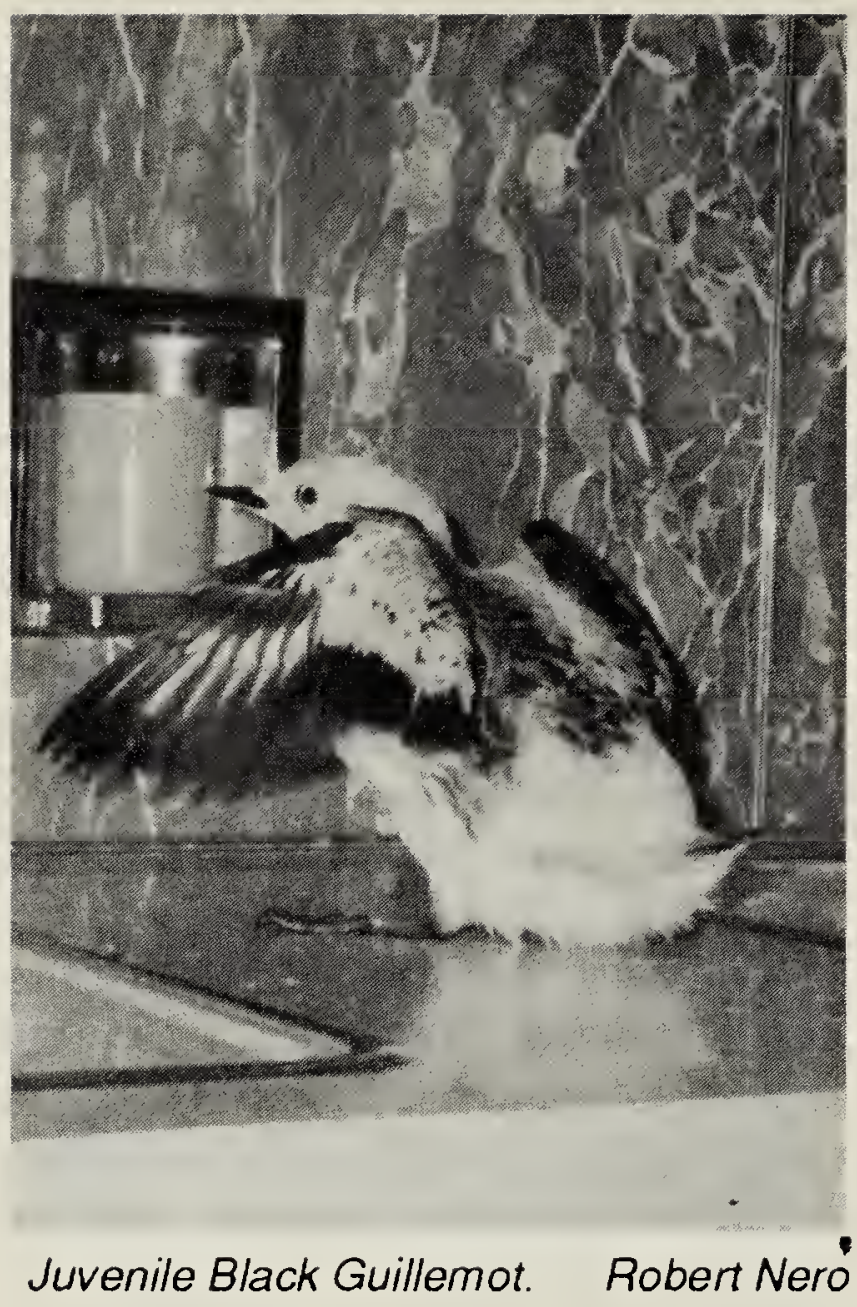

record), one at Morris, Manitoba, 12 November 1966 (first Manitoba record), one south of Churchill, 8 March 1974, and the present specimen. ${ }^{1,2,3}$

1. BEST, R. 1974. Wintering record of the Black Guillemot off northern Manitoba. Blue Jay 32:163.

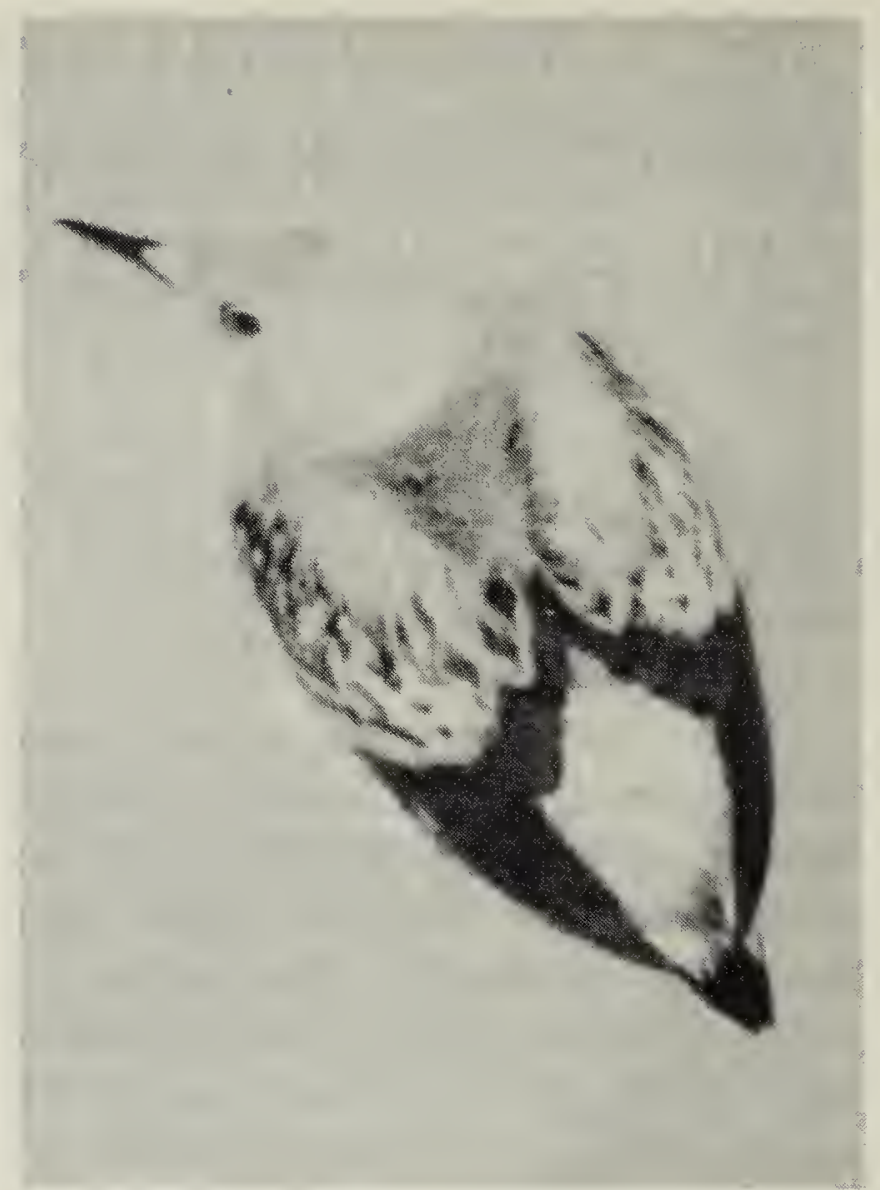

Juvenile Black Guillemot in rehabilitation.

Robert Nero

2. NERO, R.W. 1968. Manitoba Black Guillemot specimen. Blue Jay 26: 14-15.

3. SIROIS, J. 1991. First record of the Black Guillemot near Yellowknife, Northwest Territories. Blue Jay 49: 33-35.

[When introduced] the English sparrow ... was hailed as a foe of the cankerworm. Peter Matthiessen, 1959. Wildlife in America. Viking, New York. 